$10-2017$

\title{
Book Review: Justifying Genocide: Germany and the Armenians from Bismarck to Hitler
}

Vahram Ter-Matevosyan

American University of Armenia

Follow this and additional works at: https://digitalcommons.usf.edu/gsp

\section{Recommended Citation}

Ter-Matevosyan, Vahram (2017) "Book Review: Justifying Genocide: Germany and the Armenians from Bismarck to Hitler," Genocide Studies and Prevention: An International Journal: Vol. 11: Iss. 2: 106-108. DOI:

http://doi.org/10.5038/1911-9933.11.2.1482

Available at: https://digitalcommons.usf.edu/gsp/vol11/iss2/10

This Book Review is brought to you for free and open access by the Open Access Journals at Digital Commons @ University of South Florida. It has been accepted for inclusion in Genocide Studies and Prevention: An International Journal by an authorized editor of Digital Commons @ University of South Florida. For more information, please contact digitalcommons@usf.edu. 
Book Review: Justifying Genocide: Germany and the Armenians from Bismarck to Hitler

\author{
Vahram Ter-Matevosyan \\ American University of Armenia \\ Yerevan, Armenia
}

Justifying Genocide: Germany and the Armenians from Bismarck to Hitler

Stefan Ihrig

Cambridge, Harvard University Press, 2016

472 Pages; Price: $\$ 35.00$ Hardcover

Reviewed by Vahram Ter-Matevosyan

Institute of Oriental Studies, National Academy of Sciences of Armenia; American University of Armenia

In June 2016 the German Parliament adopted a resolution declaring the killings of Armenians and other Christian minorities in 1915 a genocide. The resolution once again raised questions about the depth and extent of Germany's role in the Armenian Genocide. In the last twenty years there have been a number of books and articles which explored the German responsibility in the Armenian Genocide. With his second monograph, Stefan Ihrig, Polonsky Fellow at the Van Leer Jerusalem Institute, takes an important step in enriching the existing interpretations. The book is consisted of four parts divided into fifteen chapters and covering a period from 1878 to the Holocaust. It opens a new perspective on the role that Germany played in the making of the Armenian Genocide and how it was discussed in Germany. It is worth noting that reading of the previous book by Stefan Ihrig ${ }^{1}$ will make understanding of the second one much easier. There are not only references to that book and a few, albeit important, thematic repetitions but also a number of arguments that can be better understood after reading the first book.

This book has a number of objectives which aim to reframe the German understanding and exploitation of the Armenian Question by providing two closely intertwined contexts - the German and the German-Ottoman. The other objective of the book, as it was also the case with the first one, is about comprehending the process of learning - how the Germans learnt from the Ottomans, and how the Ottomans learnt from Germany, how they empowered each other by providing political, military, diplomatic and most importantly moral support. This particularly concerns the German help that was extended to the Ottomans. Although the book is not about the Armenian Genocide, it successfully integrates the Armenian Genocide into world and twentieth-century history. If approached from these perspectives, the book has clearly met its objectives. If the author tried to approach the problem in the context of only WWI or WWII, little could have been clear about the German roots of anti-Armenianism and the binding features of the German-Ottoman alliance. Instead, the author broadened the chronological spectrum, which allowed him to widen the context and provide more evidence.

It brings into the fore the roots of German anti-Armenianism and Armenia-related paranoia and builds an entire argument based on the assumption that Germany's role needs to be seen as one which justified the Armenian massacres in the 1890s and later the Armenian Genocide in 1915. These approaches laid foundation for, what the author claims, "the great German Genocide discourse" in the early 1920s. The book argues that throughout the period under consideration, the printed discourse in Germany was mostly pro-Turkish, which rationalized the massacres against the Armenians. The Armenian massacres in the 1890s were widely covered in the German press, which used the term Völkemord long before Lemkin coined it in English. The book extensively discusses the parallels between Jews and Armenians which were widely known in Germany. Popular intellectuals and right wing press presented Armenians under negative circumstances,

\footnotetext{
${ }^{1}$ Stefan Ihrig, Atatürk in the Nazi Imagination (Cambridge: Belknap Press of Harvard University Press, 2014). Vahram TerMatevosyan, Review of "Atatürk in the Nazi Imagination" by Stefan Ihrig, International Journal of Armenian Genocide Studies 2, no. 1 (2015), 87-92.
} 
which permeated all the politically relevant German spheres. Stefan Ihrig discusses a number of widely read books of the time by Karl May, Hans Barth, Alfred Körte which were widely known for their anti-Armenian clichés. The German media, which was extensively discussed in Ihrig's previous book too, also played a pivotal role in spreading virulent anti-Armenian bias. The book presents a plethora of justifications that existed in Turkey and which were borrowed by Germany. The images of Ottoman Armenians were shaped by stereotypes, assumptions, rationalizations. The Ottomans manipulated the German press by injecting dominant images of Armenians as being "treacherous," "disloyal," "backstabbers," "fifth column," "people who are able to stab-in-theback" and the German press embraced them without much questioning.

The author also does not avoid raising a number of questions which are widely seen as inconvenient ones. For instance, to the question of "What could Germany have known about the Armenian Genocide," he plainly states, "everything." ${ }^{2}$ It also touches upon the questions of the German guilt, (co)responsibility and complicity in the Armenian Genocide by drawing a line between existing views in the historiography (Vahakn Dadrian, Donald Bloxham) and his approaches. He finds not convincing Dadrian's claim that the Armenian Genocide was a result of joint German-Ottoman decision making; however, he adds that Germany was guilty in failing to stop the Young Turks.

The book also discusses questions related to the Turkish knowledge of German tactics, military culture and lessons that the Ottoman army leadership employed while planning the Armenian Genocide. The author also argues that since many German high-ranking officers, military advisers had reformed and transformed the Ottoman military academy and had taught people like Enver Pasha, there is enough reason to assume that "German tactics," "traumatic experiences, and military culture were well known and had been absorbed by part of the Ottoman army leadership." ${ }^{3}$ Deriving from this assumption, the book also sees a continuation of methods between genocide of Herero and Nama people in German Southwest Africa (1904-1907), brutal atrocities in Belgium committed by Germans (1915-1916) and the Armenian Genocide. Based on Isabelle Hull's observations of the ideas, logic and warfare that German military culture was permeated with, Ihrig argues that the Young Turk leaders were affected by "the German army's excesses vis-à-vis the civilian population" and the common belief that victory could not be imagined in any other way than total destruction of the enemy." ${ }^{4}$ Hence, the book argues that the Young Turks knew quite well that for the victory in any war civilians should be targeted as well.

More importantly, the book traces parallels and paradigmatic continuities between the Armenian Genocide and the Holocaust by looking at the former through the lenses of Nazi Germany. Interestingly, Armenians were presented in the racial anthropological and racial texts through the lenses of anti-Semitism. For that purpose, the author discusses a number of popular books by Felix von Luschan, Carl Helm, Theodor Fritsch, Houston Chamberlain, Albrecht Wirth, Henry Ford etc., where Armenians were presented under predominantly negative conditions.

The book is also about struggle and hope against the crime of humanity. It features four people who desperately fought against indifference and negligence of the German authorities. Franz Werfel, Armin Wegner, Max-Erwin Scheubner-Richter and Johannes Lepsius are the people who tried to reverse the tide, inform the public, stop the killing machine and even warn the German people about the upcoming Holocaust. Although the author wants the reader to remember the four pro-Armenian "protagonists," whose names constantly appear in the text, however, no less important is the story of Soghomon Tehlirian. His assassination of Talat Pasha in 1921 in Berlin intensified the discussion of the Armenian Genocide in Germany. His appearance also changed the flow of events in the book. "One of the spectacular trials of the twentieth century," which lasted only one and a half days, did not find Tehlirian guilty for the murder of the one of the masterminds of the Armenian Genocide. ${ }^{5}$ Although the trial and its "spectacular verdict" are widely covered in

\footnotetext{
${ }^{2}$ Ibid., 94 .

${ }^{3}$ Ibid., 97.

${ }^{4}$ Ibid., 96.

${ }^{5}$ Ibid., 235.
} 
the historiography, Stefan Ihrig puts the trial into a different context by bringing into it other key figures. Their names either were widely known before the trial or would become known in the coming decades. The trial was a turning point in Germany, Armenia and in the Armenian Genocide discourse and the author analyses it in greater detail, which helps the reader to understand its significance and implications for the great German genocide discourse.

In light of these discussions, one of the important contributions of the book is its central argument, which claims that the factor of the justifiers of the Armenian Genocide and, any other Genocide for that matter, needs to be revisited. The Armenian Genocide, which Ihrig refers to as "the double original sin... of the twentieth century," is mostly approached from the perspective of denialists and perpetrators, whereas the role and the significance of the justifiers and bystanders remain unexplored. ${ }^{6}$ Stefan Ihrig proves that considering the justifiers' argument for the study of the Armenian Genocide is quite critical. He brings evidence to suggest that Germany could turn the tide if it did not seek their own plans of annihilation of Jews.

Although the book raised a number of questions and answers them as deep as possible, the author aspires to be careful in providing definitive answers to a host of other inconvenient questions. He challenges the reader to think about the problems that he could not find explanations. Also, before reaching the final chapters it remains quite unclear about the roots of the German anti-Armenianism. Why would Germany care so much about Armenians? - is a question that the readers struggles with before $\mathrm{s} /$ he reaches the chapters where a deep analysis is provided.

Overall, two books of Stefan Ihrig complement each other and reading only one of them will leave many questions unanswered. With this book Stefan Ihrig defies not only the deep-seated concepts and approaches about the Armenian Genocide discourse, but he also revisits the German history.

${ }^{6}$ Ibid., 7. 